
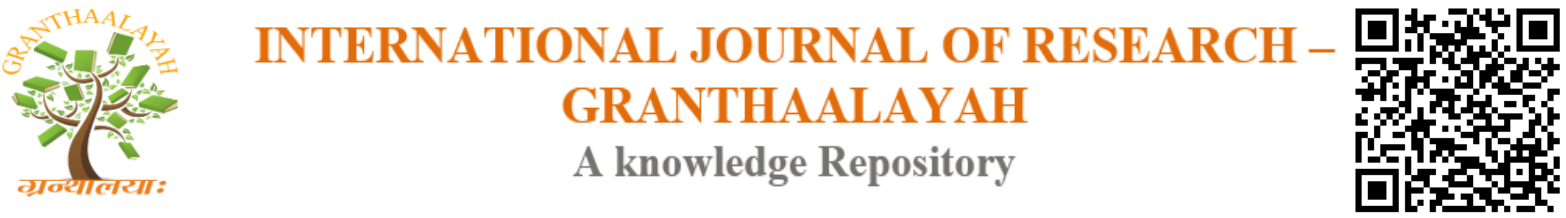

Science

\title{
PARTICIPATION OF SCIENCE TEACHERS IN BUDGETING FOR INSTRUCTIONAL RESOURCES SECONDARY SCHOOLS IN KENYA
}

\author{
Charles Richard Oyier ${ }^{1}$, Paul Amollo Odundo ${ }^{2}$ \\ ${ }^{1,2}$ Department of Educational Communication and Technology, University of Nairobi, Kenya
}

\begin{abstract}
Planning for instructional resources demands that money be set aside and budgeted for to make them available and adequate in secondary schools. To adequately avail science instructional resources a policy driven budgeting process is essential. The influence of budgeting process on instructional management and the extent of involvement of science teachers have not been highlighted through empirical data. This study adopted stakeholder theory and obtained information from science teachers in secondary schools within Nairobi County, Kenya. From 96 science teachers in 33 secondary schools of Nairobi County obtained using stratified random samplings. 89 filled questionnaires. Findings of this study established that science teachers are involved in the budgeting process for sourcing of instructional resources in Kenyan secondary schools was considered in terms of their participation in strategic planning (mean 3.20), departmental meetings (mean 3.46), and budgeting committee (mean of 3.33) and in pre-budget consultations (mean of 3.33) and post-budget consultations (mean of 3.31) (mean of 3.42).
\end{abstract}

Keywords: Instructional Resources; Budgeting Process; Strategic Planning; Budgeting Committee; Pre- and Post-Budget Consultations.

Cite This Article: Charles Richard Oyier, and Paul Amollo Odundo. (2017). "PARTICIPATION OF SCIENCE TEACHERS IN BUDGETING FOR INSTRUCTIONAL RESOURCES SECONDARY SCHOOLS IN KENYA.” International Journal of Research - Granthaalayah, 5(8), 236-251. https://doi.org/10.29121/granthaalayah.v5.i8.2017.2219.

\section{Introduction}

Provision of quality science instructions is valuable because it is a pillar in development in any nation. Acknowledging this, Odhong' (2014) noted that science education is a precursor for national technological and economic advancement globally. Further, Mukhwana (2013) asserted that sciences subjects equip learners with manipulative skills necessary for technological development and economic growth. To raise quality of science education proper planning for instructional resources is essential. Proper planning for science instructional resources according to Hammond (2007) demands that money be set aside through a budgeting process. This will ensure availability and adequacy of instructional resources in secondary schools for the desired learning outcome. Agreeing with this argument Validya (2003) noted that adequate budgetary 
allocation for instructional resources would ensure good learning outcomes for sciences and this is vital in technological advancement. Adequate budgetary allocation for science instructional resources require participatory role of science teachers on decisions and especially in budgeting process at secondary schools. This study linked learning achievements in science to utilization of instructional resources through budgeting process in secondary schools in Nairobi County. To enhance utilization of science instructional resources participation of teachers in budgeting process from planning, monitoring and control. This according to Kitheka (2005) will ensure availability of funds for sourcing science instructional resources for effective utilization throughout the year. Involvement of science teachers in budgeting for instructional resources maximizes their utilization and in turn results in better learning outcomes. Summing up this Asayo (2009) asserted learning outcomes in science depends on budgetary allocation decisions to proper utilization instructional resources.

\subsection{Budgeting for Science Instructional Resources}

Planning for instruction starts with school budgeting process to determine budgetary allocations for instructional resources. Once budgeted for, instructional resources are made available for teachers to plan for utilization for the purpose of effective learning of science subjects in the classroom. Budgeting process is a system of rules governing decision making that leads to a budget, from formulation, through approval, to its execution (Roza, 2009). In secondary schools, budgeting process is considered as a decision making process that uses information to allocate finite resources to prioritized institutional needs. According to Bisschoff and Mestry (2003) budgeting process involves relationships and communication with stakeholders within school community among them teachers and non-teaching staff. Enlisting cooperation of science teachers ensures a comprehensive view of the budget and a feeling of partnership which contributes to the much needed quality education through effective instructions. Supporting this position, Purnamasari and Rahmawati (2014) asserted that budgeting for instructional resources is an aspect of educational planning which requires participation of teachers for the purpose of promoting quality science instruction and learning outcomes. This study considered science teachers as key stakeholders required to fully participate in budgeting process for instructional resources for their respective subjects in secondary schools in Nairobi County, Kenya. The study intended to provide empirical evidence that would support the role of science teachers on budgetary allocations for instructional resources in secondary schools. Kaguri, Njati, and Thiaine (2014)

\subsection{Science Teachers and Budgeting for Instructional Resources}

In a study on effectiveness of secondary schools principals in United Kingdom, Jason, Grissom and Loeb (2009) argued that principals as managers should have support of their colleagues in managing their institutions. For effective science instructional management, principals need support for respective subject teachers in school budgeting process to ensure adequate budgetary allocation for teaching and learning resources. Echoing Grissom and Loeb (2009) asserted that in collaborating with science teachers in budgeting process would make instructional resources more available and better utilized. Effective utilization is a determinant of good learning outcome and overall performance of the school. Jason, Grissom and Loeb (2009) found out that secondary principal' organizational management skills predicts learning achievement, learners 
growth and other success measured. This resonates with Robinson et al (2008) assertion that secondary school principals require collaborative management skills in working with science teachers. In collaborating with science teachers secondary school principals can adequately provide instructional resources through a budgeting process. Science teachers are key in establishing instructional objectives and expectations; strategic resourcing; planning, coordinating, and ensuring an orderly and learning environment. This study explored secondary schools organizational management skill in collaborating with science teachers in instructional management through budgeting process.

\subsection{Role of Science Teachers in Strategic Planning}

A strategic planning exercise builds on people's creativity and collective consensus, respecting people's priorities and choices. According to Mulwa (2005), strategic plan should have milestones clearly indicating what each set of actions is expected to lead. In secondary schools, strategic plans' milestones in instructional management would include as sourcing and making resources available for effective science instructions. However, according to Mbugua and Rarieya (2014) secondary schools in Kenya have not fully embraced strategic planning. This study sought from secondary school science teachers and principals the availability of strategic plans in their institutions and whether those in plans quality science instruction through appropriate utilization of instructional resources as one of the milestones. Wanjala and Rarieya (2014) in an article on possibilities and challenges on strategic planning in schools in Kenya, revealed that limited knowledge and awareness reduce its effectiveness as an instructional management tool. Further they found out that stakeholders in strategic planning process are involved in different ways. In their study Onguko, Abdalla and Webber (2008), noted that some schools do not engage staff in the strategic planning process, instead hire consultants to make it or simply borrowing and adopting from other schools. However, this study hypothesized that secondary schools have variations in their contextual needs, which requires each to have its uniquely developed strategic plan. Further, this study the focused was the extent to which science teachers take part in school strategic planning where objectives informing budgetary allocations for instructional resources are set.

\subsection{Science Teachers and Departmental Meetings}

One way in which science teachers can participate in school budgeting process is through departmental meetings. According Wadesango (2012), departmental meetings provide a participative decision making platform and is an important contributor toward successful instructional management. Ideally, science teachers have a role in decisions that lead to budgetary allocations for instructional resources during departmental meetings. Agreeing with this position Witty (2003) asserted that departments have a role to ensure quality instructions and overall sailing in the academic spheres. At the departmental meetings science teachers would prioritize on quality and quantity of instructional resources necessary for effective instructions aimed at good learning outcome. This study investigated the role of science teachers in decisions leading to budgetary allocations for instructional resources. Mathu (2013) in a study of perceptions of teachers and principals on the role of Head of Department in Secondary School in Kiambu County noted that departmental meetings provide a platform for cooperative planning to identify instructional needs for science instructional resources. During such meetings, 
departmental budgets should be drawn after deliberations are touching on subject requirements per class and forward such to the school budgeting committee. However, as noted by Oplatka (2004) autocratic leadership style common in most secondary schools is characterized by lack of collaborative approach in instructional management would reduce budgetary decision role of departmental meeting. Therefore, it was vital to establish the level of participation of science teachers in budgeting process through departmental meetings

\subsection{Science Teachers and Budgeting Committee}

In budgeting committees, head of science or a representative teacher and those from other departments receives departmental priorities which are then brought together to facilitate drawing of the final school budget. Mokoena (2011) suggested that science teachers and other stakeholders need to be given opportunity to play defined and legitimate roles in school budgeting process. This study explored possibility of secondary schools in Nairobi County having budgeting committees with science teachers represented purposely for appropriate budgetary allocations for instructional resources. This was partly informed by Hussien (2015) findings in a study to assess the practices of teachers' participation in school decision-making in secondary schools in Ethiopia, where it was indicated that committees existing were only concerned with curriculum and instruction. Secondary schools leadership need to establish a budgeting committee with representation from science department as a step towards linking financial leadership to instructional management. However, this depends on principals' perception of teachers' ability and the role they could play in instructional management. Confirming this Sharp and Walker (2005) asserted that secondary school principals consider teachers to be less knowledgeable on financial management issues. Several reason including minimal trust, lack of budgeting knowledge and absence of motivation of teachers could explain this apparent lack of participatory leadership. However in this study, the concern was on representation of science teachers in budgeting committees as a determinant of budgetary allocation for instructional resources

\subsection{Science Teachers and Budgetary Consultations}

Consultations between budgeting committees and Science teachers before and after the school budget drawn are likely to affect the overall instructional management. Pre-budget consultation is one way of ensuring that the school budget effectively addresses issues to do with instructional resources. Echoing this position Drah (2011) in a study on teachers' participation in decision making process in senior high and technical schools in the Kwaebibirem district in the eastern region of Ghana, recommended that there should be pre-budget consultations between budgeting committees, science department and individual subject teacher for effective instructional management. This study sought to establish existence of pre-budget consultations on budgetary priorities in regard to science instructional resources in secondary schools in Nairobi County. A post-budget consultation enables adjustments for adequate allocation for instructional resources for sciences by appropriating given amount for instructional resources before adoption of the budget. This position is also held by Kosgei and Kimengi (2007) in paper presented at the Kenya Association of Educational Administration and Management, (KAEAM) Conference on effectiveness of HODs in school budgeting. However, they also recommended that after budgetary allocations have been made by the budgeting committee recognition of expertise of 
science teachers in their respective subject and teaching methodology through post budget consultations would be vital. Kosgei and Kimengi (2007) surveyed selected districts in North Rift, but this study focussed on secondary schools of Nairobi, county.

\section{Statement of the Problem}

Appropriate instructional resources are required for effective science teaching in secondary schools. This can only be realized through adequate budgetary allocation as noted by (Jebet \& Naserian, 2003). Much work has been done on availability, adequacy and utilization of instructional resources and their influence on learning outcome. However, a gap of knowledge exists to link the role of science teachers in budgeting process and utilization of instructional resources in Kenyan secondary schools. The influence of budgeting process on instructional management and the extent of involvement of science teachers have not been highlighted through empirical data. Secondly, it was needful to determine the role of science teachers as stakeholders in strategic planning to set milestones in instructional management; in departmental meetings to prioritize on appropriate instructional resources; in budgeting committee for adequate representation of science instructional interests; and in both pre and post budgeting consultations for trade-ins and adjustments to ensure adequate budgetary allocations for instructional resources.

\section{Theoretical Framework}

This study adopted stakeholder theory which argues that the organization has relationships with many constituent groups and that it can engender and maintain the support of these groups by considering and balancing their relevant interests (Kipkoech and Chesire, 2011). Stakeholder theory fronted by Ian Mitroff in 1983 would explain the need for involvement school decisionmaking processes could have a positive significance on learning achievements in biology, chemistry and physics. From corporate world it is proven to be popular with both those interested in profits and those interested in ethics. This could not be much different in educational management. As noted by Hoy and Miskel (2008) budgeting in secondary schools is complex to be performed by a single individual, the requisite knowledge and skills are collaboratively found among the staff. Emphasis on stakeholder theory is managerial in the broad sense of that term in that it portrays secondary school principals as managers who should pay simultaneous attention to the legitimate interests of all appropriate stakeholders, both in financial leadership and instructional management to enhance quality of science education

\section{Purpose of the Study}

The purpose of this study was to determine the role of science teachers in budgeting for science instructional resources in Secondary schools in Nairobi County

\section{Methodological Approach}

This study was descriptive survey in targeting science teacher public and private secondary schools that have been in existence more than 10 years offering the national 8-4-4 curriculum in Nairobi County, Kenya. In Nairobi County there are 6 national schools, 60 county schools and 
66 private schools in Nairobi County. From 96 science teachers in 33 secondary schools obtained using stratified random samplings. 89 filled questionnaires. Quantitative data obtained was analyzed through creation of simple tables that showed the frequency to establish the role of science teachers in secondary schools budgeting for instructional resources.

\section{Findings}

In this study the sample was made up of 2 national, 15 county and 16 private schools. Out of 33 sampled secondary schools data was collected from 29. Out of these, 2(6.70\%) of the sampled secondary schools were national secondary schools, $15(51.72 \%)$ were county secondary schools and $12(41.38 \%)$ were private secondary schools.

\subsection{Characteristics of Science Teachers}

A qualified secondary school science teacher holds a teaching certificate, licensed by the TSC and has at least a diploma in education qualifications from a recognized institution and well qualified to teach either biology, chemistry or physics. In this study, at least one science teacher for any of the three subjects were asked to fill questionnaires in the sampled schools. Analysis of results obtained from 83 science teachers who participated is presented in Table 1

Table 1: Characteristics of Science Teachers

\begin{tabular}{llll}
\hline Variable & & Frequency & Percentage \\
\hline Gender & Male & 39 & $47.00 \%$ \\
Qualifications & Female & 44 & $53.00 \%$ \\
& Graduate & 75 & $90.50 \%$ \\
Age & Post-Graduate & 8 & $9.50 \%$ \\
& 31-40 years & 40 & $48.20 \%$ \\
Experience & 41-50 years & 28 & $33.70 \%$ \\
& Over 50 years & 11 & $13.30 \%$ \\
& 5 years and below & 2 & $2.40 \%$ \\
& 6-10years & 34 & $41.00 \%$ \\
Duration & 11-15years & 23 & $27.70 \%$ \\
Current & 16-20years & 11 & $13.30 \%$ \\
Station & Over 20years & 13 & $15.70 \%$ \\
& 5 years and below & 38 & $45.70 \%$ \\
& 6-10years & 38 & $45.70 \%$ \\
Teaching & 11-15years & 5 & $6.20 \%$ \\
Subject & 16-20 years & 1 & $1.20 \%$ \\
& Over 20years & 1 & $1.20 \%$ \\
\hline
\end{tabular}

Gender: This study took into consideration Olembo, Wanga and Karugu (1992) and De Grauwe et al (2011), arguments that teachers' involvement budgeting process for budgetary allocations for instructional resources is a vital aspect of decision-making that is not dictated by ones' 
gender. Out of 83 science teachers who fully filled questionnaires, as shown on Table 1 females science teachers were 44(53.00\%), while males science teachers were 39(47.00\%). These findings indicate that both female and male teachers participated in science instructional process in the study area. Gender of science teachers does not influence budgetary decision for instructional resources as well as their utilization. This is in line with Burusic, Babarovic and Seric (2012) findings that interaction effects of teachers' and learners' gender on school achievement are generally insignificant.

Academic Qualifications: Effectiveness of science teachers' participation in instructional planning is factor of competence derived from professional training. According to Okorie (2001) availability and appropriate utilization of instructional resources are made is dependent on professional training and influences learning outcomes. As shown in Table 1 this study all science teachers were graduates out of which $8(9.50 \%)$ had post graduate qualifications.

Age: Graduate science teachers in secondary schools mostly join the profession at an average age of 25 years (Yala \& Wanjohi, 2011). Findings in Table 1 indicates that a majority $40(48.20 \%)$ of science teachers were aged between 31-40 years old. This age group are professionals with 5 to 15 years of experience with necessary competency to participate in budgeting for science instructional resources. Twenty eight $(33.70 \%)$ of science teachers were 41-50years old, 11(13.30\%) above 50years old and only 4(4.50\%) were below 30years. This was an indication that science teachers in secondary schools in Nairobi County had teaching experience that would enable them to effectively participate in budgetary decision making and utilization of instructional resources.

Experience: Experience enhances competency in decision making. According to Song, Hans van der Bij and Mathieu (2005) there is a positive relationship between teacher experiences and learning outcomes. Findings on the experience of science teachers in secondary schools in Nairobi County as indicated in Table 1 showed that those with 6-10 years of experience were $34(41.0 \%)$. Those with 11-15years were 23(27.70\%), 13(15.70\%) had over 50years, 11(13.30\%) had 16-20years while $2(2.40 \%) 5$ or less years. These findings showed that more than half science teachers had teaching experience necessary for effective participation in budgetary decision making and utilization of instructional resources. This finding concurs with a study conducted by Somech (2002) which asserted that 5 years is adequate experience for teacher to effectively participate in management related decision making.

Experience in the Current Stations: Work experience of a science teachers determine the ease with which they understand school financial and instructional management policies, their implementation mechanisms and monitoring frameworks. From Table 1, 38(45.70\%) of science teachers had served in their schools for 5years or less, another 38(45.70\%) for 6-10years, $5(6.20 \%)$ for 11-15years, 1(1.20\%) for 16-20 years and 1(1.20\%) for over 20 years. This was an indication that $45(54.30 \%$ ) out of 83 science teachers had more than five years in their respective schools. The length science teachers have stayed in their respective schools, their academic qualifications and overall experience would have a positive significance in participation budgetary decision making. 
Teaching Subjects: In secondary schools science teachers can teach biology, chemistry or physics with another subject. Table 1 shows that $28(33.7 \%)$ were teachers of physics, $28(33.70 \%)$ were teachers of chemistry and $27(32.50 \%)$ were teachers of biology. Science teachers as subject teachers are instructional managers and plays a vital role in planning for classroom instruction. Planning for science instructions is decisions making process that start at writing scheme of work and includes taking part in school budgeting process which has an influence in utilization of instructional resources during teaching and learning process (Olembo, Wanga \& Karugu 1992).

\subsection{Science Teachers Participation in School Budgeting Process}

The results of their response was tabulated in Table 2

Table 2: Response on Stakeholder Participation

\begin{tabular}{|c|c|c|c|}
\hline Descriptive Statistics & $\mathbf{N}$ & Mean & $\begin{array}{l}\text { Std. } \\
\text { Deviation }\end{array}$ \\
\hline $\begin{array}{l}\text { Science teachers take part in school strategic planning where } \\
\text { objectives informing budgetary allocations for instructional } \\
\text { resources are set. }\end{array}$ & 83 & 3.20 & 619 \\
\hline $\begin{array}{l}\text { Science teachers participate in Budgeting through } \\
\text { Departmental Meetings }\end{array}$ & 83 & 3.46 & .501 \\
\hline $\begin{array}{l}\text { Science teachers are represented in the school budgeting } \\
\text { committee }\end{array}$ & 83 & 3.33 & .517 \\
\hline $\begin{array}{l}\text { There are pre-budget consultations about budgetary } \\
\text { priorities between budgeting committee and science } \\
\text { department }\end{array}$ & 83 & 3.31 & .496 \\
\hline $\begin{array}{l}\text { There are post-budget consultations between budgeting } \\
\text { committee and science department to reconcile pre-budget } \\
\text { understandings with actual allocations. }\end{array}$ & 83 & 3.42 & .485 \\
\hline
\end{tabular}

\section{Strategic Planning}

The response of science teachers on their participation in school strategic planning according to Table 2 gave a mean of 3.20 and standard deviation of 0.619 . A mean of 3.20 was an indication that science teachers agree that they take part in strategic planning process, but the standard deviation of 0.619 shows a variation which could be attributed to two reasons in secondary schools management. First, as noted by Mbugua and Rarieya (2014), secondary schools in Kenya have not fully embraced strategic planning and the process could be lacking. Secondly, some secondary schools leadership do not engage staff in the strategic planning process. They instead hire consultants to make it or simply borrowing and adopting from other schools (Onguko, Abdalla \& Webber 2008). Lack of participation of science teachers in strategic planning is an indication of failure of secondary schools to have a unifying roadmap showing directions towards achieving educational goals and linking financial leadership to instructional management. Secondary schools have variations in their contextual needs, which requires each to have its uniquely developed strategic plan. However, according to Mulkeen (2007) secondary 
schools could be lacking capacity and capability to successfully engage in strategic planning processes. This could lead to different levels of participation of science teachers and perception on the role of the strategic plan in influencing budgetary allocations for instructional resources. Table 3 represents responses from science teachers on the availability of strategic plans

Table 3: Science Teachers and Strategic Planning

\begin{tabular}{lllll}
\hline School category & Disagree & Uncertain & Agree & Total \\
\hline National & 1 & 3 & 2 & $\mathbf{6}$ \\
County & 3 & 22 & 16 & $\mathbf{4 1}$ \\
Private & 6 & 21 & 9 & $\mathbf{3 6}$ \\
Total & $\mathbf{1 0}(\mathbf{1 2 . 0 0 \% )}$ & $\mathbf{4 6}(\mathbf{5 5 . 4 0 \% )}$ & $\mathbf{2 7}(\mathbf{3 2 . 5 0 \% )}$ & $\mathbf{8 3}$ \\
\hline
\end{tabular}

Findings in Table 3 indicates that $55.40 \%$ (46) of science teachers were uncertain if schools' strategic plans have objectives informing budgetary allocations for instructional resources, $32.50 \%$ (27) agreed and $12.00 \%$ (10) disagreed. This is an indication that majority of secondary schools in Nairobi County could not be having strategic plans and if they have either science teachers did not have an opportunity of seeing them or are not aware of their existence. It is also an indication that some secondary schools in Nairobi County have not fully embraced strategic plans as instructional management tools as suggested by Kipkoech and Chesire (2011). Linking strategic planning with budgeting process through clearly defined milestones would significantly influence utilization of science instructional resources if teachers are involved at all steps in management decision (Adaire, 2010). .Table 3, further shows analysis of science teachers' involvement in terms of category secondary schools. Out of 6 six science teachers from national secondary schools only 2 agreed, in county category out of 41 science teachers 16 agreed, while among private secondary schools 9 out 36 science teach they take part in school strategic planning where objectives informing budgetary allocations for instructional resources are set.. This translated into $33.3 \%$ approval for national secondary schools, 39\% for county schools and $25 \%$ for private schools. This is an indication of low participation of science teachers in strategic planning in Nairobi county secondary schools. As noted by Jones and George (2009), strategic planning requires involvement of all stakeholders concerned with its implementation. This in turn creates a challenge for secondary schools in Nairobi County to build a mental bridge towards attainment of educational goals by linking financial leadership and budgetary allocations for instructional resources

\subsection{Departmental Meetings}

Science teachers could participate in school budgeting process through departmental meetings. This provides a participative decision making platform and a vital contributor towards successful instructional management. In seeking participation of science teachers in school budgeting process through departmental meetings, the results obtained. In Table 2 gave a mean of 3.46 and standard deviation of 0.501 . Mean of 3.46 indicated that in Nairobi county secondary schools science teachers participated in budgeting process through departmental meetings. It further indicated that science teachers had a role in decisions that lead to budgetary allocations for instructional resources. Departmental meetings provide a platform cooperative planning to identify instructional needs for science instructional resources. During such meetings departmental budgets are drawn after deliberations touching on subjects' requirements per class 
for forwarding to the school budgeting committee. However, the extent to which this is possible depends on individual secondary schools approach to financial leadership. This prompted further analysis of individual science teacher response as shown in Table 4

Table 4: Science Teachers and Departmental Meetings

\begin{tabular}{lllllll}
\hline $\begin{array}{l}\text { School } \\
\text { category }\end{array}$ & $\begin{array}{l}\text { Strongly } \\
\text { Disagree }\end{array}$ & Disagree & Uncertain & Agree & $\begin{array}{l}\text { Strongly } \\
\text { Agree }\end{array}$ & Total \\
\hline National & 0 & 0 & 1 & 5 & 0 & $\mathbf{6}$ \\
County & 1 & 4 & 14 & 19 & 3 & $\mathbf{4 1}$ \\
Private & 0 & 5 & 13 & 17 & 1 & $\mathbf{3 6}$ \\
Total & $\mathbf{1 ( 1 . 2 0 \% )}$ & $\mathbf{9 ( 1 0 . 8 0 \% )}$ & $\mathbf{2 8}(\mathbf{3 3 . 7 0 \%})$ & $\mathbf{4 1}(\mathbf{4 9 . 4 0 \% )}$ & $\mathbf{4}(\mathbf{4 . 8 0 \% )}$ & $\mathbf{8 3}$ \\
\hline
\end{tabular}

Findings in Table 4 indicate that $49.40 \%$ (41) agreed with $4.80 \%$ (4) strongly agreed, $33.70 \%$ (28) were uncertain, $10.80 \%$ (9) disagreed and $1.20 \%$ (1) strongly disagreed. This was indication that half of science teachers agreed or strongly agreed that departmental meetings had significance on budgetary allocations for instructional resources in secondary schools in Nairobi County. However, the other half that were either uncertain or disagreed indicated less consideration of departmental meetings inputs in budgeting process for instructional resources (Sharp \& Walker, 2005). Several reasons could explain why in some secondary schools departmental meetings are insignificant in terms of influencing budgetary allocations decisions for instructional resources. These could include absence of participatory leadership, minimal trust, and lack of budgeting knowledge to absence of motivation of teachers. Further, according to secondary schools categories Table 4.17, out 6 science teachers from national secondary schools in Nairobi County 5 agreed,; 19 science teachers out of 41 agreed with 3 strongly agreeing, 14 uncertain, 4 disagreeing and 1 strong disagreeing. In private category out of 36 science teachers 17, agreed with 1 strongly agreeing, 13 uncertain and 5 disagreeing. This gave an indication that in national secondary schools departmental meetings had more significance in decisions making regarding budgetary allocations for instructional resources. However, in all categories there was significant participation of science teachers in school budgeting process through departmental meetings and this would influence utilization of science instructional resources in secondary schools in Nairobi County.

\subsection{Budgeting Committee}

A departmental meeting provides earlier scrutiny of instructional resources needs per subject in each class. As noted by Wadesago (2011) teachers' participation in school decision making should not end at departmental meetings but should be carried to the budgeting committee. Including science teachers in secondary schools budgeting committee is mandatory for the attainment of better learning outcomes. In budgeting committees, head of science or a representative teacher and those from other departments receive departmental priorities which are then brought together to facilitate the drawing of the final school budget. On representation of science teachers in secondary school budgeting committee, the response obtained according to Table 4.15 indicates a mean of 3.33 with a standard deviation of 0.517 . This was an indication that science teachers in Nairobi County secondary schools were represented in budgeting committee. These findings are in concurrence with Mokoena (2011) suggestion that science teachers and other stakeholders need to be given opportunity to play defined and legitimate roles 
in school budgeting process. However, standard deviation of 0.517 showed variation on science teachers' perception of their representation in budgeting committee. This variation could be seen when individual responses were analysed as presented in Table 5

Table 5: Science Teachers and Budgeting Committee

\begin{tabular}{lllllll}
\hline $\begin{array}{l}\text { School } \\
\text { category }\end{array}$ & $\begin{array}{l}\text { Strongly } \\
\text { Disagree }\end{array}$ & Disagree & Uncertain & Agree & $\begin{array}{l}\text { Strongly } \\
\text { Agree }\end{array}$ & Total \\
\hline National & 0 & 0 & 3 & 2 & 1 & $\mathbf{6}$ \\
County & 0 & 7 & 13 & 19 & 2 & $\mathbf{4 1}$ \\
Private & 1 & 6 & 16 & 11 & 2 & $\mathbf{3 6}$ \\
Total & $\mathbf{1 ( 1 . 2 0 \% )}$ & $\mathbf{1 3}(\mathbf{1 5 . 7 0 \% )}$ & $\mathbf{3 2}(\mathbf{3 8 . 6 0 \% )}$ & $\mathbf{3 2}(\mathbf{3 8 . 6 0 \% )}$ & $\mathbf{5 ( 6 . 0 0 \% )}$ & $\mathbf{8 3}$ \\
\hline
\end{tabular}

Findings in Table 5 indicated that majority of science teachers either were uncertain, disagreed or strongly disagreed on their participation in budgeting committee. Out of 83 science teachers $38.60 \%$ (32) agreed, 38.60\% (32) were uncertain, 6.00\% (5) strongly agreed, 15.70\% (13) disagreed and $1.20 \%$ (1) strongly disagreed that they were represented in the budgeting committee. These results revealed a greater variation in science teachers' participation in decision on budgetary allocations for instructional resources at budgeting committee level in Nairobi County secondary schools. This reflected Kumbi (2015) study in Ethiopia which ascertained that some teachers had a greater participation in school management decision making while others are not involved. Variation in level of participation of science teachers in management decision making has a significant influence on availability and utilization of instructional resources in secondary schools in Nairobi County. In terms of school categories as presented in Table 5, results showed that about half of science teachers from public secondary schools either agreed or were strongly agreeing that they were represented in school budgeting committee compared to about a third in private schools. However, the fact that $38.60 \%$ (32) were uncertain, $15.70 \%$ (13) disagreed and $1.20 \%$ (1) strongly disagreed that they were represented in budgeting committee was a perceptive variation. This is attributed to different approaches secondary schools leadership have in financial and instructional management. This would significantly influence availability and utilization of science instructional resources.

\subsection{Pre-Budget Consultations}

In seeking to establish the role of science teachers in pre-budget consultations the findings obtained Table 4.15) gave a mean of 3.31 with a standard deviation of 4.96. This was an indication that pre-budget consultations take place in secondary schools in Nairobi County. However, a standard deviation of 4.96 indicated a variation in response from science teachers which could be attributed to different approaches in secondary schools financial leadership in regard to budgeting process and instructional management. Several reason could explain this absence of participatory leadership. Such may include minimal trust, and lack of budgeting knowledge and lack of motivation from science teachers. This findings echoes Sharp and Walker (2005) assertion that some secondary school principals could be considering science teachers to be less knowledgeable on financial management issues. This came more clearly in analysis of individual science teachers responses presents in Table 6 
Table 6: Science Teachers and Pre Budgeting Consolations by Category of Schools

\begin{tabular}{lllllll}
\hline $\begin{array}{l}\text { School } \\
\text { category }\end{array}$ & $\begin{array}{l}\text { Strongly } \\
\text { Disagree }\end{array}$ & Disagree & Uncertain & Agree & $\begin{array}{l}\text { Strongly } \\
\text { Agree }\end{array}$ & Total \\
\hline National & 1 & 0 & 2 & 1 & 2 & $\mathbf{6}$ \\
County & 1 & 7 & 14 & 17 & 2 & $\mathbf{4 1}$ \\
Private & 0 & 5 & 17 & 12 & 2 & $\mathbf{3 6}$ \\
Total & $\mathbf{2 ( 2 . 4 \% )}$ & $\mathbf{1 2}(\mathbf{1 4 . 5 \% )}$ & $\mathbf{3 3 ( 3 9 . 8 \% )}$ & $\mathbf{3 0}(\mathbf{3 6 . 1 \%})$ & $\mathbf{6}(\mathbf{7 . 2 \%})$ & $\mathbf{8 3}$ \\
\hline
\end{tabular}

Findings in Table 6 showed that out of 83 science teachers who responded $39.80 \%$ (33) were uncertain, $36.10 \%$ (30) agreed, $7.20 \%$ (6) strongly agreed and $14.50 \%$ (12) disagreed with $2.40 \%$ (2) strongly disagreeing. The large number of uncertain science teachers resonates with Sharp and Walker (2005) and Kipkoech and Chesire (2011) assertion that teachers in secondary schools managerial abilities remain unrecognized and unmet because some principals take up most of the managerial decisions. Perception of secondary schools principals would therefore influence utilization of instructional resources. Since it is determined by the level of participation of science teachers in decision making in secondary schools. Failure in some secondary schools to have pre-budget consultations could also be viewed as lack of professionalism in the management of finances and principals' attitude towards management of resources that make them not involve staff in decision making concerning finances (Wagithunu et al, 2015). It could also be pegged on individual teachers' attitude. According to Kumbi (2015) some teachers are not interested in matters beyond classroom affairs unknowingly that they are part of school instructional management. It is therefore possible to conclude that pre-budget consultations can be explains in terms secondary schools principals' perceptions on their staff ability in financial management and science teachers' attitude towards their role beyond instructional process.

\subsection{Post-Budget Consultations}

In seeking to establish the existence of post-budget consultations from science teachers in secondary schools within Nairobi County as presented in Table 2 a mean of 3.42 and standard deviation of 0.485 was obtained. This was an indication that that considerable post-budgeting consultation between budgeting committee and science department takes place in secondary schools in Nairobi County. In turn this would have a significant influence in utilization of science instructional resources. Post-budget consultations are vital link between budgeting committee and science teachers which would positively impact on utilization of instructional resources and in turn improvement on learning outcomes. Involving science teachers in school budgeting process ensures adequate budgetary allocation for instructional resources. However, the nature of science teachers' involvement in post-budget consultations may differ from one secondary school to another. According to this study, it was necessary to establish how individual teachers perceived post-budget consolations in their respective secondary schools as presented in Table 7

Table 7: Science Teachers and Post Budget Consultations by Schools Category

\begin{tabular}{lllllll}
\hline $\begin{array}{l}\text { School } \\
\text { category }\end{array}$ & $\begin{array}{l}\text { Strongly } \\
\text { Disagree }\end{array}$ & Disagree & Uncertain & Agree & \multicolumn{3}{c}{$\begin{array}{l}\text { Strongly } \\
\text { Agree }\end{array}$} & Total \\
\hline National & 0 & 2 & 0 & 4 & 0 & $\mathbf{6}$ \\
County & 1 & 5 & 12 & 17 & 6 & $\mathbf{4 1}$ \\
\hline
\end{tabular}




\begin{tabular}{lllllll}
\hline Private & 1 & 3 & 16 & 16 & 0 & $\mathbf{3 6}$ \\
Total & $\mathbf{2}(\mathbf{2 . 4 \%})$ & $\mathbf{1 0}(\mathbf{1 2 . 0} \%)$ & $\mathbf{2 8}(\mathbf{3 3 . 7 \%})$ & $\mathbf{3 7}(\mathbf{4 4 . 6 \% )}$ & $\mathbf{6 ( 7 . 2 \% )}$ & $\mathbf{8 3}$ \\
\hline
\end{tabular}

Findings Table7 indicated that a majority of $44.60 \%$ (37) of science teachers agreed $7.20 \%$ (6) strongly agreed, $33.70 \%$ (28) were uncertain, $12.00 \%$ (10) disagreed and $2.40 \%$ (2) strongly disagreed. This was an indication that post-budget consultations between budgeting committee and science department to reconcile pre-budget understandings with actual allocations takes place in secondary schools in Nairobi County. This corrects what Wanzare (2006) noted about most secondary schools that little consideration is given to instructional resources during budgeting process. With active post-budget consultations, whatever budgetary allocation, necessary adjustments could be made to ensure appropriate utilization of science instructional resources. From these study findings it is possible to argue that some secondary school principals understand and appreciate the involvement of teachers in budgeting process as way towards improved utilization of science instructional resources. Table 4.20 revealed this difference in financial leadership in different categories of secondary schools in Nairobi County. For example out of 6 science teachers from national secondary schools 4 agreed and 2 disagreed that postbudget consultations between budgeting committee and science department take place in their institutions. In county schools, out of 41 science teachers 17 agreed, 6 strongly agreed, 12 were uncertain, 5 disagreed and 1 strongly disagreed. In private schools, out of 36 science teachers 16 agreed, 16 were uncertain, 3 disagreed and 1 strongly disagreed. Above analysis showed that two-thirds of national secondary schools science teachers acknowledged existence of post-budget consultations, about a half in the county category and less than half from the private counterparts. These findings indicate that more science teachers in public secondary schools than their private counterparts confirmed that post-budget consultations between budgeting committee and science department. These findings were an indication of the extent science teachers are in involved in financial management issues and particularly post-budget consultation is more evident in public schools. This variations in post-budget consultations between budgeting committee and science department among other factors could have a negative significance on learning achievements in science subject in private secondary schools than in public ones.

\section{Conclusion}

Science instructional management requires a roadmap that stems from secondary school strategic plan. The strategic plan gives directions in a set of defines actions that would influence budgetary allocations for science instructional resources. It must also have milestones clearly indicating what each set of actions is expected to lead and this should be integrated in both school instructional and financial management policy. For this reason it important to have science teachers represented during strategic planning because milestones in instructional management would include as sourcing and making teaching and learning resources available will be discussed. School strategic planning process requires science teachers' creativity in building collective consensus on priorities and choices regarding milestones in instructional management direction. The challenge is most secondary schools in Kenya have not fully embraced strategic planning as tool towards successful instructional management. Secondly, some schools do not engage staff in the strategic planning process, instead hire consultants to make it simply borrowing and adopting from other schools. Schools have variations in their contextual needs, which requires each to have its uniquely developed strategic plan, but 
according, but lack of capacity and capability to successfully engage in the processes is another challenge.

Departmental meetings provide a participative decision making platform on which science teachers discuss issues geared toward successful instructional management. These include discussion of appropriate instructional resources and forwarding to the budgeting committee for consideration. Secondly departmental meetings provide a platform cooperative planning on pedagogical needs and utilization of science instructional resources. Apart from building trust departmental meetings have a role to ensure quality instructions and overall sailing in the science performance in examinations. Science teachers' participation in school instructional management decision making should note end at departmental meetings but should be carried to the budgeting committee. Through representation the earlier scrutiny of instructional resources needs per subject in each class at the departmental level would help the budgeting committee in prioritization in a more democratic way for the attainment of schools' educational goals. In budgeting committees, head of science or a representative teacher and those from other departments receives departmental priorities which are then brought together to facilitate the drawing of the final school budget.

Another platform on which science teachers would play a role in determination of budgetary allocations for instructional resources is pre-budget consultations. This will involve building consensus between budgeting committee, science department and individual subject teacher as to effectively address issues to do with instructional resources. Pre-budget consultations only take place where school leadership is innovative, interactive and dynamic with budgeting process with the view of coming up with a balance budget. Science teachers and other staff members need to be brought, in some way or other, into budgetary decision-making if they are to remain supportive of what budgeting committee is doing. It means that the principal as instructional manager must create a participatory environment in budgeting process to ensure adequate budgetary allocations for teaching and learning resources. No single budget is perfectly representative on demands from different sections and departments, hence the need of post budget consultations. After budgetary allocations have been made by the budgeting committee recognition of expertise of science teachers in their respective subject and teaching methodology through post budget consultations is of importance. This will enable necessary adjustments to ensure adequate allocation for instructional resources for sciences is provides for before the budget adoption given amount of funds at disposal for the school within the year. This vital link between budgeting committee and science teachers will correct and make adjustment on their instructional plans

In conclusion, involving science teachers in budgeting for instructional resources is an aspect of decentralizing secondary schools management. Their participation in budgeting for instructional resources has a relationship with learning outcomes in Biology, Chemistry and Physics in secondary schools. It is therefore vital for secondary schools principals to embrace participation of science teachers in the day-to-day financial aspects of instructional management as key aspect towards attainment of good learning outcomes. This study has provided empirical evidence that links secondary schools leadership and learning outcomes through involvement of science teachers. It also indicates that secondary schools principals' leadership approach would predicts learning achievement in sciences. This is because leadership approaches determine the extent of 
teacher inclusion in decision-making and has a significant influence on overall school performance. Strategic approaches to finance and budgeting in secondary schools shows appreciation to the role of science in instructional management and enhances utilization of teaching and learning resources.

\section{Recommendations}

The study recommends that there is need for a Policy framework to define the role of science teachers in budgeting process in secondary schools. In practice, this study recommends that science teachers need to be involve in decision making in instructional management related process from strategic planning, budget planning, budget monitoring and budget control. On further research this study recommends work to be on ole of science teachers in instructional management decision making

\section{References}

[1] Davies, B. (2004) A strategic approach to finance and budgeting. In: B Davies, J West-Deegan, C. and Unerman, J. (2011) Financial Accounting Theory 2nd European Edition UK; Mc Graw-Hill Higher Education

[2] De Grauwe, Anton and Candy Lugaz with Tiberius Barasa, Pulane J. Lefoka, MathaboTsepa, Samuel Kayabwe and Wilson Asiimwe (2011) Strengthening Local Actors: The Path to Decentralizing Education, Kenya, Uganda, and Lesotho, Paris: IIEP and UNESCO।

[3] Drah, S. T. 2011. Teachers' participation in decision making process in senior high and technical Schools in the Kwaebibirem district in the eastern region of Ghana. M.A.Thesis, University of Cape Coast.

[4] Gichohi G W (2015). Stakeholder involvement in Schools in 21st Century for Academic Excellence. International Journal of Education and Research Vol. $3 \quad$ No. 2 February 2015

[5] Hammond L. (2007). Educational Leadership: A Bridge to School Reform. A Paper Presented at the Wallace Foundation Conference.

[6] Hoy W and Miskel C G (2013) Educational Administration: theory practice and research 9th edition www.amazon.com

[7] Kaguri M, Njati I C, Thiaine K S. (2014) Financial Management Challenges Facing Implementation of Free Day Secondary Education in Imenti North District, Kenya Journal of Business and Management Volume 16, Issue 1. Ver. III (Jan. 2014), PP 55-78

[8] Kipkoech L C \& Chesire S (2011). The Levels of Teachers' Involvement in Managerial Decision Making In Schools in Kenya. Problems of education in the 21st century 34, 2011 pp79-87

[9] Kitheka, A. M: (2005): Factors Contributing to Students Poor Performance in the Kenya Certificate of Secondary Education. Unpublished Med Thesis Kenyatta University

[10] Kosgei, Z. K. \& Kimengi, I. N. (2007). Factors Influencing the Effectiveness of Heads of Departments (H.O.D's) In Secondary School Management in Kenya: A Survey of Selected Districts in Rift-Valley Province; Paper presented at the Kenya Association of Educational Administration and Management, KAEAM Conference, Eldoret, 9th-11th April 2007. Abstract no. 4, Available at http://www.kaeam.or.ke/abstracts/4.htm

[11] Kumbi H. J. (2015). Teachers' Participation in School Decision Making in Secondary Schools of Arsi Zone. Unpublished M.A Thesis of Haramaya University, Haramaya

[12] Mathu P W (2013). Perceptions of Teachers, Principals and HODS on the Roles of a Secondary School Head of Department in Kiambu County, Kenya Unpublished Master's Thesis Kenyatta University 
[13] Mbugua, F. \& Rarieya, J. (2014), Collaborative Strategic Planning: Myth or Reality?, Educational Management Administration and Leadership 42(1): 99-111.

[14] Mokoena S. 2011. Participative Decision-Making perception of School Stakeholders in South Africa. University of South Africa.

[15] Mukhwana W J (2013). The Role of Student-Related Factors in the Performance of Subject in Secondary Schools in Eldoret Municipality, Kenya. Journal of Emerging Trends in Educational Research and Policy Studies (JETERAPS) 4(1): $\quad 64-73$

[16] Mulkeen, A. (2007), Recruiting, Retaining, and Retraining Secondary School Teachers and Principals in Sub-Saharan Africa (Washington, DC: World Bank).

[17] Okumbe,J.A.(2007).Educational Management; Theory and Practice. Nairobi; Nairobi University Press

[18] Olembo, J.O., Wanga, P.E.,\&Karagu,N.M.(1992).Management in Education. Nairobi; Educational Research and Publications

[19] Onguko, B., Abdalla, M., \& Webber, C.F. (2008) Mapping Principal Preparation in Kenya and Tanzania, Journal of Educational Administration 46(6): 715-726.

[20] Purnamasari, D. I and Rahmawati I. (2014). Information Processing Theory in Budgetary Participation: Its Antecedent and Consequence, International Journal of Computer Networks and Communications Security Management Guide for Headteachers; Training Module Nairobi; Government Printer

[21] Republic of Kenya (2012): Public Finance Management Act 2012 Government Printer Nairobi

[22] Republic of Kenya (2013): Basic Education Act 2013. Government Printer Nairobi

[23] Roza, M. (2009). Breaking down school budgets. Education Next, 9(3) Retrieved from: http://educationnext.org/breaking-down-school-budgets-2/

[24] Sharp WL, Walter JK 2005. The Principal as School Manager. Lanham: Rowman and Littlefield Education.

[25] Vegas, E. (2007) 'Teacher Labor Markets in Developing Countries: Improving Outcomes for Poor Students through Community Management and Better Pay for Teachers', The Future of Children 17.1: 219-32

[26] Wadesango, N (2011). Strategies of teacher participation in decision making in schools. Journal of Social Science. 27(2):85-91.

[27] Wadesango, N. 2012. The Influence of Teachers Participation in Decision-Making on their Occupational Morale. Waltersisulu University. East London, Republic of South Africa.

[28] Wagithunu N M, Muthee J and Thinguri R (2014), A Critical Analysis of School Principals' Competence in Financial Management in Kenya: Accountability in Educational Planning and Management. Journal of Education and Practice, Vol.5, No.25, 2014

[29] Walter, K.E. (2009). Making Good Choices: Sustainable School Improvement. Portland, OR: Northwest Regional Educational Laboratory. .

[30] Wanzare, Z.O. (2006).Rethinking School Inspection in the Third World; The Case of Kenya http;www.ualberta.ca.ckreberpaperszak.utm Retrieved 21/6/2013

*Corresponding author.

E-mail address: oyier1212@yahoo.com/odundopaul@yahoo.com 